\title{
SOCIAL EDUCATORS AND THEIR OPTIONS OF PREVENTIVE ACTIONS AT ELEMENTARY SCHOOLS
}

\author{
Lucie Blaštíková
}

\begin{abstract}
Our article deals with the environment of elementary school, which is specific in many respects. Our goal does not consist in analyzing in all factors that shape and influence the elementary school environment, but we focus primarily on the area of preventive actions, at the level of primary prevention in relation to pupils of higher elementary school (10-15 year old pupils). Such actions are most frequently implemented by the school prevention methodist at the elementary school. However, at present, also other professions are developed to be active in the area of prevention at the elementary school. Our goal consists in introducing and describing the options of preventive actions of the social educator at the elementary school. The article analyzes crucial documents dealing with prevention. We further offer some results of studies concerning the issue of risk behaviour in connection with the profession of social educator.
\end{abstract}

\section{Keywords}

environment of elementary school, primary prevention in relation to pupils, documents dealing with prevention

\section{Profession of social educator at the elementary school}

It is not very easy to determine the profession of social educator in the Czech conditions, as the profession is not stipulated in the Czech legislation and in the job catalogue. Nevertheless, at present it is possible to study the discipline of social education at selected Czech universities. The question is, where can the graduates of such disciplines find a job? The answer to this question is complicated both for practice and for academic 
environment. Based on the current legislation, the graduates can find a job of social educator in many areas. One of them is, of course, the area of labour and social matters where the graduate can execute the role of social worker, social probation officer for children and youth or worker at Employment Offices. The above stated options are based on Act No. 108/2006 Coll., on social services, as amended (Zákon č. 108/2006 Sb., 2006). Another area is certainly the area of education. According to Act No. 563/2004 Coll., on educators, as amended, the social educator can work as leisure time educator, instructor and educator's assistant (MŠMT, 2004b). It should be mentioned that in Slovakia, our neighbour country, the situation is different. The social educator is confirmed by legislation, in Act No. 317/2009 Coll., on professional and educational employees (Zákon č. 317/2009 Z. z., 2009). The Act defines the social educator as a professional employee. Our goal consists in focusing on the elementary school environment in which social educators work within the above stated professions, but also as members of school advisory centres at positions of social educators at present. We face some obstacles here, specifically the job content, which is not defined, and the funding of this position. ${ }^{1}$ Bakošová speaks about the activities of social educator in school environment as follows: "The social-educational activities of social educator at schools are qualified professional activities, implemented directly at school and not having teaching but upbringing character. They reduce the load of stressed teachers and work with children and youth who need help at harmonizing relations, at different dysfunctions, disharmonious family, peer, school or broader environment, and they lead to improve the quality of their lives. In narrower sense, children need to compensate undesirable problems by desirable matters, they need to understand and shape values, desirable habits that have not been developed in their existing environment so far. Activities focused on problems derived from unsuitable upbringing, socialization and communication and activities focused on elimination of socially pathological phenomena hold a specific place." (Bakošová, 2015). We agree with the definition and think, similarly to Bakošová, that the activities of social educators at elementary school concern children and youth showing risk behaviours, but also children and youth not showing risk behaviours but harmonious development.

The profession of social educator in school environment is discussed also by Zemančíková who speaks about the area of social upbringing, support in many areas of children's and young people's development and about the area of prevention of socially pathological phenomena. (Zemančíková, 2014). Notable authors who deal with the activities of social educators include also Ondrejkovič, Hroncová, Hudecová, Emmerová. We could also draw from Polish representatives of social pedagogy like Walancik, Kucharczyk, Pikiewicz and others. We have many notable representatives in the Czech environment too; Kraus is indisputably one of them and he defines the profession of social educator as follows: "That worker controls and organizes the upbringing process professionally and acts upon the upbringing process subjects at two levels:

1. Integrational level - the social educator focuses on persons (clients) who need professional help and support (people in crisis situations, in psychological, social or psycho-social danger, who become an obstacle to their environment).

\footnotetext{
${ }^{1}$ Due to the focus of the text, we will not discuss in more detail the funding of the position of social educator.
} 
2. Developmental level - the social educator supports and strengthens the desirable development of personality that should head towards the right life style and valuable and useful spending of leisure time; that is actually social prevention concerning the whole population, particularly children and youth." (Kraus, 2014)

At the same time, Kraus comments the activities executed by the social educator, dividing them into three areas. The first area consists in adequate content of leisure time; the second area consists in advisory activities; and the third area consists in field and screening activities. (Kraus, 2014)

If consulting the above stated Slovak Act No. 317/2009 Coll., we can see that its $\S 24$ delimits that social educator performs "professional activities in the scope of prevention, intervention and counselling particularly for children and pupils endangered by socially pathological phenomena, coming from socially disadvantaged environment, drugaddicted or otherwise disadvantaged pupils, their legal representatives and teachers." (Zákon č. 317/2009 Z. z., 2009)

In 2015, a study ${ }^{2}$ was implemented with a partially goal focused on defining the job content of social educator at the elementary school. Based on the study, the job content of social educator was defined in the following points. (Blaštíková, 2015)

- Preventive activities - the social educator participates in preventive activities and closely cooperates with the school prevention methodist.

- School advisory centre - the social educator acts within the centre as informant about the situation in the catchment area of the school and about the events at school.

- Procedures for ascertainment of risk behaviour - the school must have clearly defined procedures for the case of detection of a risk behaviour; therefore the social educator is involved in creation of minimal preventive program of the school and of other documents in the area of prevention.

- Establishing contacts with the parents - based on the study, this area was identified as one of the most challenging ones, primarily for form teachers. The social educator as a professional usually takes over this area.

- Work in classes - the social educator works directly in classes with the pupil(s). They are usually pupils showing risk behaviours and thus disturbing the whole teaching process.

- Consultations with form teachers - they consist in mutual cooperation on further steps when working with the pupils and the parents in their own interest.

We believe that based on the above stated points and of definitions, it can be stated that the area of prevention is very important within the social educator's activities, which is confirmed also by Hroncová who states: "The prevention as a focus competence of

\footnotetext{
2 The project was called "School climate and the influence of school prevention methodist and social educator upon it at elementary school". The study was implemented in five elementary schools in the Czech Republic and in three elementary schools in Slovakia. Within mixed design, semi-structured interviews were implemented with professional workers of schools.
} 
social educator, both at school and in educational institutions, must be comprehensive and interconnected. The boundaries between individual prevention types are very unstable and individual prevention types mingle into and complement each other." (Hroncová, 2015). That's why we will discuss the preventive actions of social educator at the elementary school in the next part of our text.

\section{Prevention at elementary school}

Prevention at the elementary school is related to many terms that should be defined. They include primarily risk behaviours and specific types of them. We primarily draw on Miovskýs works and on important documents including Národní strategie primární prevence rizikového chování u žákư na období 2013-2018 (National strategy of primary prevention of risk behaviour of pupils for the period of 2013-2018) (MŠMT, 2013), which is a document of the Ministry of Education, Youth and Physical Education, as well as Metodické doporučení k primární prevenci rizikového chování u dětí, žáků a studentů ve školách a školských zařizeních (Methodical recommendation to primary prevention of risk behaviour of children, pupils and students at schools and in educational institutions). (MŠMT, 2010). We consider important also the Decree No. 72/2005 Coll., on provision of advisory activities at schools and in school advisory centres, as amended (MŠMT, 2005). Prevention can be defined as follows. Prevent - "forestall, preclude" (Rejzek, 2001). Čech defines prevention in a broader context. "We define as prevention all actions heading towards forestalling and minimizing the phenomena related with risk behaviour and its consequences. Prevention may have the character of forestalling the origination, development and recurrence of a socially undesirable phenomenon." (Čech, 2012). At present, school prevention is implemented through tools resulting from the above stated documents. It includes the minimal preventive program, the school rules or the school preventive strategy. The minimal preventive program is defined by Miovský as a "specific document of the school, aimed at upbringing the pupils towards healthy life style, at their personality and social development and at the development of their socially communicative skills. It also includes specific interventions helping the pupils to acquire such knowledge, skills and capabilities (or also competences) that efficiently reduce the risk of incidence or development of specific forms of risk behaviour" (Miovský et al., 2015). The MPP is a school document that must be updated every year. It is created primarily by the school prevention methodist, but each teacher or professional school worker may be involved as well. The implemented study showed that the social educator participates strongly in the program in the context of field and screening activities. The school rules constitute a crucial document of the school; it is created by the school headmaster according to the definition of the "School Act", i.e. Act No. 561/2004 Coll., on preschool, elementary, secondary, higher professional and other education, as amended (MŠMT, 2004a). The school preventive strategy is described in the Methodical recommendation and it is a long-term strategy of work at school in relation to different groups that may have significant influence on the school environment (teachers, pupils, but also parents). 
Prevention can be subdivided in different ways; according to WHO into (Miovský, 2015):

- Primary, secondary, and tertiary.

The American Academy of Sciences divides prevention into (Černý, 2010):

- General, selective, and indicated prevention.

MŠMT divides prevention into (MŠMT, 2005):

- Specific and non-specific prevention.

The Methodical recommendation on primary prevention suggests that the school environment is primarily the scene for first-degree prevention, i.e. primary prevention that can be defined as a set of actions intended for the whole population. The elementary school prevention is focused on the following types of risk behaviours, based on the Methodical recommendation to primary prevention of risk behaviour of children, pupils and students at schools and in educational institutions. (MŠMT, 2010)

- truancy,

- bullying and aggression,

- risk sports and risk behaviours in traffic,

- racism and xenophobia,

- negative influence of sects,

- sexual risk behaviours,

- prevention in addictology,

- eating disorders,

- syndrome of mistreated, neglected and abused child.

According to Jessorov, risk behaviour should be understood as "problematic, disturbing or undesirable behaviour with respect to the norms, institutions and authorities of conventional society." (Jessorov, in Miovský, 2010).

Skopalová's study of 2014 showed that the form teachers most frequently face the following risk behaviour types - late arrivals, truancy, vulgar behaviour and aggressive behaviour. Further, the form teachers stated to face such behaviours frequently, but not to have much grasp of how to solve them. (Kupčík \& Skopalová, 2014)

We see adequate solution of the situation in the delegation of the actions to professional school employees including the school prevention methodist, special educator, upbringing advisor, career advisor, school psychologist, but also social educator. So what options does the social educator have in the area of preventive actions at the elementary school?

\section{Preventive activities of social educator}

We believe that the social educator is a significant agent who can influence both the prevention of origination of risk behaviour and its solution. With respect to the above described activities, the preventive actions are extraordinarily important. Stephens writes in his book that social pedagogy is both a scientific discipline and practice applying pedagogical solutions to social problems. It primarily strives for preventive actions of the social educator to avoid such problems. (Stephens, 2013) 
We create the areas of preventive actions based on the study from 2015, focused on mutual cooperation of social educator and school prevention methodist and on our own practice. (Blaštíková, 2015)

Field work - the field and screening activities of social educator is discussed also by Kraus (2014), but some professionals believe that that type of activities should not be included in the job content of social educator. Field work consists specifically in the educator's implementing primary and secondary prevention in the catchment area of the school, in the pupils' place of residence. Tertiary prevention should be left to other workers. Preventive actions are focused both on the pupils and on their parents, because the parents often may be the inciters of risk behaviours. Field work or also street work can be defined as one of the work methods of social workers that may be subdivided into specific stages. (Matoušek et al., 2013). Street work is described by Burke (2014) as an important part of the work that connects the internal and external school environment. He states that street work as a method may considerably influence the school in its social changes, thus contributing to elimination of risk behaviours or to improvement of the school climate. (Burke, 2014)

Cooperation with external professionals - the social educator primarily provides for cooperation of school with the authorities of social-legal protection of children, i.e. with social workers and social probation officers for children and youth according to Act No. 359/1999 Coll., on social-legal protection of children, as amended (Zákon č. 359/1999 Sb., 1999). The OSPOD often contacts the school in relation with writing down a report on the child's current status in different areas. Further, there is cooperation with the pedagogical-psychological advisory centre that focuses more on the area of developmental learning and behaviour disorders rather than on social development. Last but not least, cooperation with the Czech Police is important too, for example in the area of preventive programs, talks, lectures or suspected criminal activity of pupils or their parents. Hutyrová et al. (2013) do not underestimate the importance of cooperation of institutions, not only in the area of prevention but also of intervention and re-socialization. They include the work with risk population among interventional activities in which not only OSPOD, but also social services, pedagogical-psychological advisory centres, special pedagogical centres and upbringing care centres are involved. They also do not omit the important cooperation with the family. (Hutyrová et al., 2013). We see space for the social educator here, both in establishing cooperation in the school environment and in field.

Preventive programs - as was stated above, the social educator participates in the creation of the minimal preventive program, but cooperates with the school prevention methodist also at other programs prepared by the school. Programs provided by external experts are of course implemented at schools. Nevertheless, in view of the specific structure of the pupils, it is sometimes better to create own programs related to the current difficulties and behaviours of the pupils of the school. The coordination of the preventive programs takes place at vertical level as well as at horizontal level. We believe that the vertical coordination is more important for this text; that coordination includes 
the Regional methodical centre - the regional anti-drug coordinator, the regional school prevention coordinator, the criminality prevention coordinator or the coordinator for Roma matters. Further, the system includes consulting activities by the school prevention methodist, the school headmaster, the form teacher or the prevention methodist of the pedagogical-psychological advisory centre. (Doležalová, in Miovský et al., 2015). Further, we would mention the basic types of preventive programs according to Gabrhelík (in Miovský et al., 2015):

- Programs focused on the development of life skills (we can include programs focused on decision-making skills or programs focused on training of social skills).

- Programs focused on intrapersonal development (programs focused on values and scale of values or programs focused on building positive self-image).

As for the social educator's work in the area of prevention, we consider it important to mention also programs for parents or peer programs aimed at prevention of risk behaviour.

The article discusses the profession of social educator and the specific activities implemented by the social educator at the elementary school. The article also states basic information from the area of prevention, which is primarily aimed at specific options of preventive actions of the social educator. In view of the continuously developing risk behaviour at schools, we believe that distinctive engagement in the field of prevention is necessary, not only from the position of the school prevention methodist. The above stated study (Kupčík \& Skopalová, 2014) confirms that teachers face different types of risk behaviours, but that they do not dispose of adequate competences to solve them adequately. Although the profession of social educator is not defined by legislation in the Czech environment, selected elementary schools (primarily in the South Moravian Region) have social educators in their school advisory centres and the social educators are distinctively engaged in preventive activities.

\section{References}

Bakošová, Z. (2008). Sociálna pedagogika ako životná pomoc [Social Education as Life Support] ( $3^{\text {rd }}$ extended and updated ed.). Bratislava: Public Promotion.

Bakošová, Z. (2015). Sociálny pedagóg v škole a jeho činnost’s ciel'ovými skupinami [Social Educators in Schools and Their Activities with Target Groups]. In Socialia 2015: možnosti uplatnění sociálního pedagoga/sociální pedagogiky v současné společnosti [Socialia 2015: Application Possibilities of Social Educator/Social Education in Contemporary Society]. Hradec Králové: Gaudeamus. 
Blaštíková, L. (2015). Klima školy a jeho ovlivnění školním metodikem prevence a sociálním pedagogem v základní škole [School Climate and The Influence of the School Prevention Methodologist and Social Pedagogue at Primary School]. Olomouc: Palacký University Olomouc.

Burke, C. (2014). Fleeting pockets of anarchy. Streetwork. The exploding school. Paedagogica Historica, 50(4), 433-442.

Čech, T. (2012). Prevence [Prevention]. In M. Miovský, Výkladový slovník základních pojmů školské prevence rizikového chování [Expository Dictionary of Basic Concepts of Educational Prevention of Risk Behavior] (pp. 107-112). Prague: Charles University.

Černý, M. (2010). Základní úrovně provádění primární prevence [The Basic Level of Implementation of Primary Prevention]. In M. Miovský, L. Skácelová, J. Zapletalová, P. Novák, et al., Primární prevence rizikového chování ve školách [Primary Prevention of Risk Behavior in Schools] (pp. 42-43). Prague: Association SCAN, Charles University.

Hroncová, J. (2015). Súčasné problémy a možnosti d’alšieho vzdelávania sociálnych pedagógov v praxi a participácia Banskobystrickej školy sociálnej pedagogiky na jeho realizácii [Current Problems and Possibilities of Life-Long Education of Social Educators in Practice and the Participation of the Banská Bystrica School of Social Education on Its Implementation]. In Socialia 2015: možnosti uplatnění sociálního pedagoga/sociální pedagogiky v současné společnosti [Socialia 2015: Application Possibilities of Social Educator/Social Education in Contemporary Society]. Hradec Králové: Gaudeamus.

Hutyrová, M. et al. (2013). Prevence rizikového a problémového chování [Prevention of Risk and Problem Behaviours]. Olomouc: Palacký University Olomouc.

Kraus, B. (2014). Základy sociální pedagogiky [Basics of Social Pedagogy]. Prague: Portál.

Kupčík, O., \& Skopalová, J. (2014). Klima třídy na 2. stupni základních škol z hlediska projevư rizikového chování ve třídě [The Class Climate at Second Stage of Primary Schools in View of Risk Behaviour in the Class]. [DVD]. Olomouc: Palacký University Olomouc.

Matoušek, O. et al. (2013). Metody a řizení sociální práce [Methods and Management of Social Work]. Prague: Portál.

Miovský, M. (2010). Historie a současné pojetí primární prevence rizikového chování $\checkmark$ České republice [History and Current Concept of Primary Prevention of Risk Behaviour in the Czech Republic]. In M. Miovský, L. Skácelová, J. Zapletalová, P. Novák, et al., Primární prevence rizikového chování ve školství [Primary Prevention of Risk Behavior in Schools] (pp. 13-28). Prague: Association SCAN, Charles University in Prague \& Togga. 
Miovský, M. (2015). Výkladový slovník základních pojmů školské prevence rizikového chování [Expository Dictionary of Basic Concepts of Educational Prevention of Risk Behavior]. Prague: Charles University, First Faculty of Medicine, Adictology Clinic.

Miovský, M. et al. (2015). Prevence rizikového chování ve školství [Risk Behaviour Prevention in Schools]. Prague: Charles University, First Faculty of Medicine, Adictology Clinic.

Miovský, M., Skácelová, L., Čablová, L., Veselá, M., \& Zapletalová, J. (2012). Návrh doporučené struktury minimálního preventivního programu prevence rizikového chování pro základní školy [The Design of Recommended Minimum Prevention Program Structure for the Prevention of Risk Behaviour for Primary School]. Prague: Charles University in Prague \& Togga.

MŠMT. (2004a). Zákon č. 561/2004 Sb., o předškolním, základním, středním, vyšším odborném a jiném vzdělávání, ve znění pozdějších předpisů [Act No. 561/2004 Coll., on Preschool, Elementary, Secondary, Higher Professional and Other Education, as Amended]. Retrieved December 7, 2016, from http://www.msmt.cz/dokumenty/novyskolsky-zakon

MŠMT. (2004b). Zákon č. 563/2004 Sb., o pedagogických pracovnících a o změně některých zákonů [Act No. 563/2004 Coll., on Educators and on the Amendment to Some Other Acts]. Retrieved December 7, 2016, from http://www.msmt.cz/dokumenty/ aktualni-zneni-zakona-o-pedagogickych-pracovnicich-k-1-lednu

MŠMT. (2005). Vyhláška č. 72/2005 Sb., o poskytování poradenských služeb ve školách a školských poradenských zařízeních, ve znění pozdějších předpisů [Decree No. 72/2005 Coll., on Provision of Advisory Activities at Schools and in School Advisory Centres, as Amended]. Retrieved December 7, 2016, from http://www.msmt.cz/dokumenty/ vyhlaska-c-72-2005-sb-1

MŠMT. (2010). Metodické doporučení k primární prevenci rizikového chování u dětí, žáků a studentů ve školách a školských zařizeních [Methodical Recommendation to Primary Prevention of Risk Behaviour of Children, Pupils and Students at Schools and in Educational Institutions]. Retrieved January 11, 2015, from www.msmt.cz/uploads/ Metodickedoporuceniuvodnicast.doc

MŠMT. (2013). Národní strategie primární prevence rizikového chování u žáků na období 2013-2018 [National Strategy of Primary Prevention of Risk Behaviour of Pupils for the Period of 2013-2018]. Retrieved December 11, 2014, from www.msmt.cz/file/20270

Rejzek, J. (2001). Etymologický slovník [Etymological Dictionary]. Voznice: Leda. 
Stephens, P. (2013). Social pedagogy: Heart and Head. Bremen: EHV.

Zákon č. 359/1999 Sb., o sociálně-právní ochraně dětí, ve znění pozdějších předpisů [Act No. 359/1999 Coll., on Social-legal Protection of Children, as Amended]. (1999). Retrieved December 19, 2016, from https://www.zakonyprolidi.cz/cs/1999-359\#cast1

Zákon č. 108/2006 Sb., o sociálních službách, ve znění pozdějších předpisů [Act No. 108/2006 Coll., on Social Services, as Amended]. (2006). Retrieved December 7, 2016, from http://www.zakonyprolidi.cz/cs/2006-108

Zákon č. 317/2009 Z. z., o pedagogických zamestnancoch a odborných zamestnancoch a o zmene a doplnení niektorých zákonov [Act No. 317/2009 Coll., on Professional and Educational Employees and on Changes and Amendments to Some Acts]. (2009). Bratislava: Ministerstvo školstva, vedy, výskumu a športu Slovenskej republiky [Ministry of Education, Science, Research and Sport of the Slovak Republic]. Retrieved December 7, 2016, from https://www.minedu.sk/6826-sk/zakon-c-3172009-z-z-o-pedagogickychzamestnancoch-a-odbornych-zamestnancoch-a-o-zmene-a-doplneni-niektorychzakonov/

Zemančíková, V. (2014). Problémové správanie žiakov a úloha sociálneho pedagóga $\checkmark$ reflexii učitel'ov [Problematic Behaviour of Students and the Role of the Social Pedagogue in Teacher's Self-assessment]. Sociální pedagogika [Social Education], 2(1), 22-36.

\section{Author}

Mgr. Lucie Blaštíková

Faculty of Humanities, Tomas Bata University in Zlín

Department of Pedagogical Sciences

Štefánikova 5670, 76001 Zlín, Czech Republic

blastikova@utb.cz 